\section{Color Stability of Ceramic Veneers Luted With Resin Cements and Pre-Heated Composites: 12 Months Follow-Up}

\author{
Brenda Procopiak Gugelmin ${ }^{1}{ }^{\circledR}$, Luiz Carlos Machado Migue ${ }^{2}{ }^{\circledR}$, Flares Baratto \\ Filho $^{1,2}$, Leonardo Fernandes da Cunha ${ }^{1}$, Gisele Maria Correr ${ }^{1}$, Carla \\ Castiglia Gonzaga ${ }^{1}$
}

'School of Health Sciences, Graduate Program of Dentistry, UP - Universidade Positivo, Curitiba, PR, Brazil

${ }^{2}$ School of Dentistry, Univille - Universidade de Joinville, Joinville, SC, Brazil

Correspondence: Carla Castiglia Gonzaga, Rua Professor Pedro Viriato Parigot de Souza, 5300, 81280-330 Curitiba, PR, Brasil. Tel: +55-41-3317-3180. e-mail: carlacgonzaga2@gmail.com

\begin{abstract}
The objective was to evaluate the color stability of ceramic veneers luted with resin cements and pre-heated composite resins $\left(60^{\circ} \mathrm{C}\right)$ for 12 months, and determine the degree of conversion (DC) of the luting agents. Two resin cements (AllCem Veneer, light-cured (LRC) and AllCem, dual-cured (DRC)] and three composite resins [Z100 (MNCR-minifilled), Herculite Classic (MHCR-micro-hybrid) and Durafill (MCCR-microfilled)] were used for cementing 0.8-mm-thick lithium-silicate glass-ceramic laminates (Suprinity, shade B2HT, Vita) on bovine enamel $(n=10)$. The specimens were stored at $37^{\circ} \mathrm{C}$ in distilled water. CIELab parameters were determined at $24 \mathrm{~h}$ after luting (baseline), 7, 30, 90, 180 days and 12 months. Three specimens were prepared for DC evaluation, performed by micro-Raman spectroscopy. Data were analyzed by ANOVA and Tukey's test $(\alpha=5 \%)$. For $\Delta \mathrm{E}_{\mathrm{ab}}$ and $\Delta \mathrm{E}_{00}$, there were significant differences for luting material $(p<0.001)$, time $(p<0.001)$, and double interaction $(p<0.001)$. The groups cemented with MHCR ( 1 year), MCCR (90 days and 1 year) and MCCR-PH (1 year) were the ones with $\triangle \mathrm{E}$ values greater than the acceptability threshold. All other groups maintained their $\Delta \mathrm{E}$ lower than the acceptability threshold after 1 year in distilled water. Regarding DC, there were no significant differences $(p=0.127)$ among the materials. Non-significant negative correlations were observed between the mean $\Delta \mathrm{E}_{\mathrm{ab}}$ and $\mathrm{DC}(\mathrm{R}=-0.65)$ and $\Delta \mathrm{E}_{00}$ and $\mathrm{DC}(\mathrm{R}=-0.64)$. A significant positive correlation was observed mean $\Delta \mathrm{E}_{\mathrm{ab}}$ and $\Delta \mathrm{E}_{00}(\mathrm{R}=0.99)$. It was concluded that the different luting agents influenced the final color of the restorations. The heating of the composite resins did not affect their DC.
\end{abstract}

Key Words: color stability, degree of conversion, ceramic veneers, resin cements, preheated composites.

\section{Introduction}

One of the major challenges for modern dentistry is to achieve the perfect optical properties of natural teeth with artificial materials (1). In general, the optical behavior of a ceramic restoration is determined by the combination of the underlying tooth structure color, the thickness of the ceramic layers, and the color of the cement (2). In clinical situations, it is essential to understand how the color of a cemented ceramic restoration may change after aging in the oral cavity. Cement layer discoloration is an important aspect to be considered when luting ceramic restorations. When compared to ceramic materials, the cement layer is chemically less stable and may undergo color changes over time. Nonetheless, the perception of color alteration due to resin cement aging may be different according to the ceramics' translucency. Therefore, clinicians should understand the factors affecting final result of indirect restorations and carefully choose restorative materials in order to achieve optimal aesthetic results (3).

Resin cements are often used for the cementation of all-ceramic restorations, as they have good esthetic and mechanical properties, low solubility in the oral environment and can be adhesively bonded to dental tissues
(4). Among luting agents, light-cured cements are widely recommended for cementation of ceramic veneers. The major advantages of these cements are color stability and longer working time, as compared to chemically activated or dual-cured resin cements $(5,6)$.

Dual-cured resin cements can also be used for cementation of ceramic veneers. These cements have better mechanical properties than light-cured or chemically activated cements, such as flexural strength, modulus of elasticity, hardness, and degree of conversion (DC) (7). However, these cements have a shorter working time, and oxidation of reactive groups of tertiary amines and inhibitors may cause changes in their color over time, especially yellowing of the cement (8). It is important to note that these compounds, amines and inhibitors, may also be found in light-cured materials, but in a smaller amount (9).

Ceramic veneers can be cemented with resin cements and with composite resins. There is a growing interest in making composite resins with higher filler content less viscous by using pre-heating, without affecting the properties of the polymerized material (10). Some of the possible advantages of pre-heating composite resins include 
better adaptation of the material to the cavity walls, lower potential for the formation of defects at the margins, increase in the $D C$ and, consequently, better physical and mechanical properties (11). As the cost of pre-heated composite resins is lower than that of resin cements and as the range of colors is maximized, they can be used as an alternative for the adhesive cementation of ceramic veneers (12). The success of ceramic restorations depends on good polymerization of resin-based materials used for cementation. Thus, understanding how the pre-heating of different composite resins used for cementation of ceramic veneers influences the $\mathrm{DC}$ could help in the clinical decision for the luting agent, aiming for long-term esthetic and functional outcomes (13).

It should be highlighted that the assessment of color stability of different luting materials plays an important role in thin translucent ceramic veneers, fabricated mainly of feldspathic ceramics and glass-ceramics, with thicknesses ranging from 0.3 to $0.9 \mathrm{~mm}$, possibly affecting their longterm success (14). Therefore, the objective of the present study was to evaluate the color stability of thin ceramic veneers luted with resin composites and pre-heated composite resins $\left(60^{\circ} \mathrm{C}\right)$ for 12 months, and determine t the degree of conversion (DC) of the luting agents. The null hypotheses were as follows: i) the different luting agents would not influence the final color of cemented thin ceramic veneers; ii) storage time would not influence the color of thin ceramic veneers, regardless of the luting material used; and iii) there would not be any difference in the DC of the evaluated luting materials.

\section{Material and Methods}

Forty pigmentation-free bovine incisors with intact crowns without visually detectable enamel cracks were selected. The shades of all teeth were determined prior to the experiments with a Vita Classical shade guide (Vita Zahnfabrik, Bad Säckingen, Baden-Württemberg, Germany), and were classified as A1, B2 or A2. Two flat surfaces were obtained using a semiautomatic polisher (Buehler MetaServ 250, Lake Bluff, IL, USA) with silicon carbide sandpapers (grit sizes 320, and 600) for 1 min under water cooling. The surfaces had at least $6 \mathrm{~mm}$ of flat area and were located only on the enamel.

After preparation of the surfaces, the specimens were randomly distributed into eight groups $(n=10)$ according to the luting agent used: LRC - light-cured resin cement; DRC - dual-cureed resin cement; MNCR - minifilled composite resin; MNCR-PH - pre-heated minifilled composite resin; MHCR - micro-hybrid composite resin; MHCR-PH - preheated micro-hybrid composite resin; MCCR - microfilled composite resin; and MCCR-PH - pre-heated microfilled composite resin. The composition of materials is described in Table 1. All resin cements and composite resins used were shade A1 (Vita Classic shade guide, Vita Zahnfabrik, Bad Säckingen, Baden-Württemberg, Germany).

Five blocks of lithium silicate-based glass-ceramics (Suprinity, shade B2-HT, Vita Zahnfabrik, Bad Säckingen, Baden-Württemberg, Germany) were cut using a low speed diamond saw (IsoMet 1000, Buehler, Lake Bluff, USA) under cooling to obtain $0.8-\mathrm{mm}$ thick ceramic veneers. The veneers were the subjected to thermal treatment under vacuum at $840{ }^{\circ} \mathrm{C}$ for $8 \mathrm{~min}$, according to the manufacturer's

Table 1. Composition of resin cements and composite resins

\begin{tabular}{lcc}
\hline Luting material & Classification & Composition \\
\hline & & Methacrylate monomers, camphorquinone, co-initiators, \\
AllCem Veneer (FGM) & Light-cured resin cement & stilicate glass particles, and silicon dioxide \\
& $63 \%$ of filler content
\end{tabular}

Cement base: methacrylate monomers, camphorquinone, co-initiators, stabilizers, pigments, barium, aluminum, and silicate glass microparticles, silicon dioxide nanoparticles, inorganic pigments, preservatives Catalyst paste: methacrylate monomers, dibenzoyl peroxide and stabilizers, barium, aluminum, and silicate glass microparticles $67 \%$ of filler content

Bis-GMA, TEGDMA, zirconia/silica $81 \%$ of filler content

Z100 (3M) Minifilled composite resin

Herculite Classic (Kerr) Micro-hybrid composite resin

Bis-GMA, TEGDMA, camphorquinone, amine, iron oxide pigments, aluminum borosilicate glass, colloidal silica ( $\mathrm{SiO2}$ ) $79 \%$ of filler content

Durafill (Kulzer)

Microfilled composite resin

UDMA, highly dispersive silicon dioxide, prepolymerized filler particles $54 \%$ of filler content

Bis-GMA: Bisphenol-A glycidyl methacrylate; TEGDMA: Tetraethylene glycol dimethacrylate; UDMA: Urethane dimethacrylate. 
recommendations.

The ceramic veneers were etched with $5 \%$ hydrofluoric acid (Condac Porcelana, FGM, Joinville, SC, Brazil) for 20 $\mathrm{s}$, washed under running water for $20 \mathrm{~s}$, and air-dried. Silane (Prosil, FGM, Joinville, SC, Brazil) was applied for $60 \mathrm{~s}$ followed by a layer of adhesive (ScotchBond Multi-Purpose, $3 \mathrm{M}$, St. Paul, MN, USA). The enamel surface was etched with 37\% phosphoric acid (Condac 37, FGM, Joinville, SC, Brazil) for $30 \mathrm{~s}$, washed for $30 \mathrm{~s}$ under running water, and air-dried. A layer of adhesive (ScotchBond Multi-Purpose, $3 \mathrm{M}$, St. Paul, MN, USA) was applied. The luting material was placed on the treated surface of the ceramic veneer. In the pre-heated composite resin groups, the luting material was placed in an oven and pre-heated at $60 \mathrm{oC}$ for $3 \mathrm{~min}$ in a dappen dish. After the heating period, the dappen dish was removed from the oven when the surfaces of the ceramic veneers and enamel were already treated. The luting material was promptly placed over the surface of the ceramic veneers. The veneers were cemented on the flat surface of the middle third of the dental enamel, with finger pressure for $10 \mathrm{~s}$ repeated until the flow of excess material was completely ceased and the veneer was fully seated onto the enamel, simulating a clinical cementation procedure. A pilot study was conducted (sixteen specimens) for standardization of the cementation procedure. These specimens were sectioned and evaluated at 40x magnification under a stereomicroscope (SZX9, Olympus, Tokyo, Japan) to determine the thickness of the luting material. The cement line was considered uniform and clinically acceptable, with thickness of 133.4 $\pm 29.0 \mu \mathrm{m}$ (coefficient of variation of $22 \%$ ). The mean cementation time for each veneer was approximately 1 min (from placing the luting material into the veneer until complete excess removal). Cementations were carried out in controlled temperature $\left(23{ }^{\circ} \mathrm{C}\right.$ ) and humidity (30 to $50 \%$ ). Light-curing of adhesive layers and of the luting agent occurred simultaneously for each veneer with a LED curing unit (Radii-Cal, SDI, Bayswater, Australia) with 1200 $\mathrm{mW} / \mathrm{cm}^{2}$ irradiance for $40 \mathrm{~s}$. The light-curing unit was fully charged before the luting procedures and the irradiance of the light-curing unit was checked using a radiometer (LED Demetron, Kerr, Middleton, WI, USA) before use. Ten minutes after light-curing, the specimens were stored in an oven, immersed in distilled water at $37^{\circ} \mathrm{C}$. The distilled water was replaced every week throughout the whole evaluation period.

Color stability after cementation was evaluated using a spectrophotometer (EasyShade Advance, Vita Zahnfabrik, Bad Säckingen, Baden-Württemberg, Germany). The specimens were dried with absorbent paper, and placed on a flat surface with a standardized white background. The spectrophotometer was calibrated before the readings. The spectrophotometer was always positioned in the center of the specimen, at a $90^{\circ}$ angle to the surface. The measurements were always made in the same environment with the same lighting conditions and at similar times of the day, to minimize the interference of the environment in the color measurements.

Color parameters were assessed $24 \mathrm{~h}$ after cementation (baseline), and subsequently at 7, 30, 90, and 180 days, and at 12 months. After each reading, the specimens were stored in distilled water at $37^{\circ} \mathrm{C}$. Color stability was assessed by determining the color difference between color measurements and baseline, using $L$, a and $b$ coordinates from the $\operatorname{CIELab}\left(\Delta \mathrm{E}_{\mathrm{ab}}\right)$ and $\mathrm{CIEDE} 2000\left(\Delta \mathrm{E}_{00}\right)$ system, where $L$ indicates luminosity, a represents the green $(-a)$ and red color $(+a)$ and $b$ represents the blue $(-b)$ and yellow $(+b)$ color. $\Delta \mathrm{E}_{\mathrm{ab}}$ was calculated using the formula $(15,16)$ :

$\Delta \mathrm{E}_{\mathrm{ab}}=\left[(\Delta \mathrm{L})^{2}+(\Delta \mathrm{a})^{2}+(\Delta \mathrm{b}) 2\right]^{1 / 2}$

where $\Delta \mathrm{L}, \Delta \mathrm{a}$ and $\Delta \mathrm{b}$ indicates difference between the final and baseline measurements for different periods for each parameter.

$\Delta \mathrm{E}_{00}$ was calculated according to the CIEDE2000 formula $(16,17)$ :

$\Delta \mathrm{E}_{00}=\left\{\left[\left(\Delta \mathrm{L}^{\prime} /(\mathrm{kLSL})\right]^{2}+\left[\Delta \mathrm{C}^{\prime} /(\mathrm{kCSC})\right]^{2}+\left[\Delta \mathrm{H}^{\prime} /(\mathrm{kHSH})\right]^{2}+\right.\right.$ $\left.\mathrm{RT}\left[\Delta \mathrm{C}^{\prime} /(\mathrm{kCSC})\right] \times\left[\Delta \mathrm{H}^{\prime} /(\mathrm{kCSC})\right]\right\}^{1 / 2}$

where $\Delta \mathrm{L}, \Delta \mathrm{C}$ and $\Delta \mathrm{H}$ are the differences in lightness, chroma, and hue for a pair of samples in CIEDE2000, and $\mathrm{RT}$ is a rotation function that accounts for the interaction between chroma and hue differences in the blue region. The weighting functions $\mathrm{SL}, \mathrm{SC}$, and $\mathrm{SH}$ adjust the total color difference for variation in the location of the color difference pair at the $\mathrm{L}, \mathrm{a}$, and $\mathrm{b}$ coordinates, and the parametric factors $\mathrm{kL}, \mathrm{kC}$, and $\mathrm{kH}$ are correction terms for experimental conditions. In the present study, $\mathrm{kL}, \mathrm{kC}$, and $\mathrm{kH}$ were set to 1 .

The $50: 50 \%$ acceptability thresholds for $\operatorname{CIELab}\left(\Delta \mathrm{E}_{\mathrm{ab}}\right)$ and CIEDE2000 $\left(\Delta \mathrm{E}_{00}\right)$ were 2.66 and 1.77 , respectively (18).

For DC measurements, disc $11 \mathrm{~mm}$ in height and 5 $\mathrm{mm}$ in diameter) specimens were prepared for the luting materials using a Teflon mold. The material was inserted in one increment and light-cured for $40 \mathrm{~s}$. The internal diameter tip of the light-curing unit was $6 \mathrm{~mm}$, and the specimen was fully positioned and centered below the tip of the curing unit during light activation. One reading per specimen was performed, with the discs carefully positioned so that the readings were made in the central area of the specimen.

For the uncured specimens, the same amount of material was used. All specimens were subjected to microRaman spectroscopy (Senterra Bruker, Ettlingen, BadenWürttemberg, Germany), with a resolution of $4 \mathrm{~cm}^{-1}$ and 32 readings at 4,000 to $800 \mathrm{~cm}^{-1}$. Peak absorbance of aromatic bonds was recorded at 1,608 $\mathrm{cm}^{-1}$ (Abs 1608) and the peak absorbance of double-bond aliphatic compounds $(\mathrm{C}=\mathrm{C})$ was 
recorded at 1,636 $\mathrm{cm}^{-1}$ (Abs 1636). Three specimens were assessed in each material.

The readings for the cured materials were performed 10 min after light-curing. During these $10 \mathrm{~min}$, the specimens were stored in dark canisters, at room temperature. The ratio between Abs 1636 and Abs 1608 was calculated for both cured and uncured materials. The percentage of remaining double bonds (RDB) was determined according to the formula:

$\% \mathrm{RDB}=$ (Abs 1636/Abs 1608 for cured material) $\times 100 /$ (Abs 1636/Abs 1608 for uncured material).

The $\%$ degree of conversion $(\% \mathrm{DC})$ of double bonds was then calculated using the formula:

$\% \mathrm{DC}=100-\% \mathrm{RDB}$

The color change data were analyzed by repeatedmeasures two-way ANOVA and Tukey's test. The DC data were analyzed by one-way ANOVA. All analyses were performed with a $5 \%$ significance level. All correlations (mean $\Delta \mathrm{E}_{\mathrm{ab}}$ or $\Delta \mathrm{E}_{00}$ in the evaluated period and the $\mathrm{DC}$; and between mean $\Delta \mathrm{E}_{\mathrm{ab}}$ and $\Delta \mathrm{E}_{00}$ in the evaluated period) were determined by Pearson's correlation coefficient.

\section{Results}

The means and standard deviations for $\Delta \mathrm{E}_{\mathrm{ab}}$ and $\Delta \mathrm{E}_{00}$ are shown in Tables 2 and 3, respectively. There were statistically significant differences for the luting material $(p<0.001)$ and time $(p<0.001)$. Double interaction was statistically significant $(p<0.001)$.

All groups had a $\Delta \mathrm{E}$ (both $\Delta \mathrm{E}_{\mathrm{ab}}$ and $\Delta \mathrm{E}_{00}$ ) lower than the acceptability threshold at 7, 30, and 180 days. The groups cemented with MHCR (1 year), MCCR (90 days and 1 year) and MCCR-PH (1 year) were the only ones with $\triangle E$ values greater than the acceptability threshold. All other groups maintained their $\Delta E$ lower than the acceptability threshold at the end of 1 year of storage in distilled water.

The DCs obtained for the luting materials are shown in Table 3. There were no statistically significant differences among the materials $(p=0.127)$. The $D C$ ranged from $64.0 \%$ (MNCR-PH) to $85.1 \%$ (DRC).

Non-significant moderate to strong negative

Table 2. Means and standard deviations of $\Delta \mathrm{E}_{\mathrm{ab}}$ for the different materials and time periods after cementation

\begin{tabular}{|c|c|c|c|c|c|c|}
\hline \multirow{2}{*}{$\begin{array}{l}\text { Luting } \\
\text { material }\end{array}$} & \multirow{2}{*}{ Temperature } & \multicolumn{5}{|c|}{$\Delta \mathrm{E}_{\mathrm{ab}}$} \\
\hline & & 7 days & 30 days & 90 days & 180 days & 1 year \\
\hline LRC & Room temperature & $1.0 \pm 0.5 \mathrm{Aa}$ & $1.5 \pm 0.5 \mathrm{Aa}$ & $1.6 \pm 0.6 \mathrm{Aa}$ & $1.7 \pm 0.5 \mathrm{Aa}$ & $2.0 \pm 0.5 \mathrm{Aa}$ \\
\hline DRC & Room temperature & $1.4 \pm 0.7 \mathrm{Aa}$ & $1.3 \pm 0.6 \mathrm{Aa}$ & $1.1 \pm 0.5 \mathrm{Aa}$ & $1.3 \pm 0.6 \mathrm{Aa}$ & $2.3 \pm 0.8 \mathrm{Aab}$ \\
\hline \multirow{2}{*}{ MNCR } & Room temperature & $2.3 \pm 0.2 \mathrm{Aa}$ & $1.6 \pm 0.5 \mathrm{Aa}$ & $2.3 \pm 0.9 \mathrm{Aab}$ & $2.0 \pm 0.8 \mathrm{Aa}$ & $2.4 \pm 0.2 \mathrm{Aab}$ \\
\hline & Pre-heated (PH) & $1.5 \pm 0.5 \mathrm{Aa}$ & $1.9 \pm 0.7 \mathrm{Aa}$ & $2.4 \pm 0.6 \mathrm{Aab}$ & $2.1 \pm 0.6 \mathrm{Aa}$ & $2.1 \pm 0.6 \mathrm{Aab}$ \\
\hline \multirow{2}{*}{ MHCR } & Room temperature & $1.8 \pm 0.8 \mathrm{Aa}$ & $1.9 \pm 0.9 \mathrm{Aa}$ & $2.1 \pm 1.3 \mathrm{Aa}$ & $2.2 \pm 1.3 \mathrm{Aa}$ & $2.7 \pm 1.4 \mathrm{Aab}$ \\
\hline & Pre-heated (PH) & $1.5 \pm 0.6 \mathrm{Aa}$ & $1.6 \pm 0.6 \mathrm{Aa}$ & $1.4 \pm 0.8 \mathrm{Aa}$ & $1.5 \pm 0.5 \mathrm{Aa}$ & $2.0 \pm 0.7 \mathrm{Aa}$ \\
\hline \multirow{2}{*}{ MCCR } & Room temperature & $2.1 \pm 0.7 \mathrm{Aa}$ & $1.7 \pm 0.9 \mathrm{Aa}$ & $2.7 \pm 1.7 \mathrm{Ab}$ & $2.4 \pm 1.2 \mathrm{ABa}$ & $3.6 \pm 1.0 \mathrm{Bab}$ \\
\hline & Pre-heated (PH) & $1.5 \pm 0.8 \mathrm{Aa}$ & $1.6 \pm 0.7 \mathrm{Aa}$ & $2.6 \pm 1.1 \mathrm{ABb}$ & $2.4 \pm 1.3 \mathrm{ABa}$ & $3.6 \pm 1.6 \mathrm{Bb}$ \\
\hline
\end{tabular}

Values followed by the same uppercase letters in the row are statistically similar ( $>0.05)$. Values followed by the same lower case letters in the columns are statistically similar ( $p>0.05)$.

Table 3. Means and standard deviations of $\Delta \mathrm{E}_{00}$ for the different materials and time periods after cementation and degree of conversion

\begin{tabular}{lccccccc}
\hline \multirow{2}{*}{$\begin{array}{l}\text { Luting } \\
\text { material }\end{array}$} & Temperature & \multicolumn{5}{c}{$\Delta$} & \multicolumn{2}{c}{$\begin{array}{c}\text { Degree of } \\
\text { conversion (\%) }\end{array}$} \\
\cline { 3 - 7 } & Room temperature & $0.6 \pm 0.2 \mathrm{Aa}$ & $0.9 \pm 0.3 \mathrm{Aa}$ & $0.9 \pm 0.3 \mathrm{Aab}$ & $1.1 \pm 0.3 \mathrm{Aa}$ & $1.3 \pm 0.3 \mathrm{Aa}$ & $78.5 \pm 4.3$ \\
\hline LRC & Room temperature & $0.8 \pm 0.4 \mathrm{Aa}$ & $0.8 \pm 0.3 \mathrm{Aa}$ & $0.7 \pm 0.3 \mathrm{Aa}$ & $0.9 \pm 0.4 \mathrm{Aa}$ & $1.6 \pm 0.5 \mathrm{Aab}$ & $85.1 \pm 11.3$ \\
DRC & Room temperature & $1.6 \pm 0.2 \mathrm{Ab}$ & $0.9 \pm 0.3 \mathrm{Aa}$ & $1.2 \pm 0.5 \mathrm{Aab}$ & $1.2 \pm 0.5 \mathrm{Aa}$ & $1.4 \pm 0.1 \mathrm{Aa}$ & $66.5 \pm 14.6$ \\
MNCR & Pre-heated (PH) & $1.0 \pm 0.3 \mathrm{Aab}$ & $1.2 \pm 0.3 \mathrm{Aa}$ & $1.5 \pm 0.5 \mathrm{Aab}$ & $1.3 \pm 0.4 \mathrm{Aa}$ & $1.3 \pm 0.4 \mathrm{Aa}$ & $64.0 \pm 9.0$ \\
& Room temperature & $1.2 \pm 0.5 \mathrm{Aab}$ & $1.2 \pm 0.6 \mathrm{Aa}$ & $1.4 \pm 0.8 \mathrm{Aab}$ & $1.4 \pm 0.9 \mathrm{Aa}$ & $1.8 \pm 1.0 \mathrm{Aab}$ & $72.9 \pm 7.7$ \\
MHCR & Pre-heated (PH) & $1.0 \pm 0.3 \mathrm{Aab}$ & $1.0 \pm 0.3 \mathrm{Aa}$ & $0.9 \pm 0.5 \mathrm{Aab}$ & $0.9 \pm 0.3 \mathrm{Aa}$ & $1.3 \pm 0.5 \mathrm{Aa}$ & $72.6 \pm 8.4$ \\
& Room temperature & $1.6 \pm 0.5 \mathrm{ABb}$ & $1.1 \pm 0.6 \mathrm{Aa}$ & $1.8 \pm 1.1 \mathrm{ABb}$ & $1.6 \pm 0.8 \mathrm{ABa}$ & $2.4 \pm 0.7 \mathrm{Bb}$ & $65.8 \pm 3.6$ \\
MCCR & Pre-heated (PH) & $1.2 \pm 0.6 \mathrm{Aab}$ & $1.0 \pm 0.5 \mathrm{Aa}$ & $1.8 \pm 0.7 \mathrm{ABb}$ & $1.5 \pm 0.8 \mathrm{ABa}$ & $2.4 \pm 1.1 \mathrm{Bb}$ & $74.1 \pm 5.6$ \\
\hline
\end{tabular}

Values followed by the same uppercase letters in the row are statistically similar $(p>0.05)$. Values followed by the same lower case letters in the columns are statistically similar ( $p>0.05)$. 
correlations were observed between the mean $\Delta \mathrm{E}_{\mathrm{ab}}$ and $\mathrm{DC}$, and $\Delta \mathrm{E}_{00}$ and $\mathrm{DC}$, with a Pearson's correlation coefficient of $-0.65(p=0.083)$ and $-0.64(p=0.089)$, respectively; indicating that the higher the DC, the lower the color change and the higher the color stability (Fig. 1). Significant strong positive correlations were observed between $\Delta \mathrm{E}_{\mathrm{ab}}$ and $\Delta \mathrm{E}_{00}$ for all evaluated times ( 7 and 30 days $=0.96 ; 90$ days $=0.97 ; 180$ days $=0.98$; and 1 year $=0.99$ ) and also considering the mean $\Delta \mathrm{E}_{\mathrm{ab}}$ and $\Delta \mathrm{E}_{00}$ values (Pearson's correlation coefficient of 0.99, $\mathrm{p}<0.001$ ) (Fig. 2).

\section{Discussion}

Luting material is a determinant factor that influences the final color of thin ceramic veneers (19). In this study, the results for luting materials are in accordance with those described in the literature, rejecting the first hypothesis, since the different luting agents influenced the final color of thin ceramic veneers. The mean $\Delta \mathrm{E}$ values were significantly different, considering the luting material, with a lower $\triangle \mathrm{E}$ values for $\mathrm{DRC}, \mathrm{LRC}$ and MHCR-PH, when compared with MCCR. A possible explanation could be the larger amount of organic matrix in relation to filler particles in microfilled resins, resulting in high water and pigment sorption rates (20).

Some studies report lower color stability in dual-cured resin cements $(12,21)$ caused by the oxidation of initiators, as well as of unreactive tertiary amines, and by the presence of unreactive benzoyl peroxide during photoactivation, leading to yellowing of the material and compromising long-term esthetics. In this study, however, the DRC had a statistically similar result to that of LRC and of some composite resins (minifilled and microhybrid, at room temperature and pre-heated). A
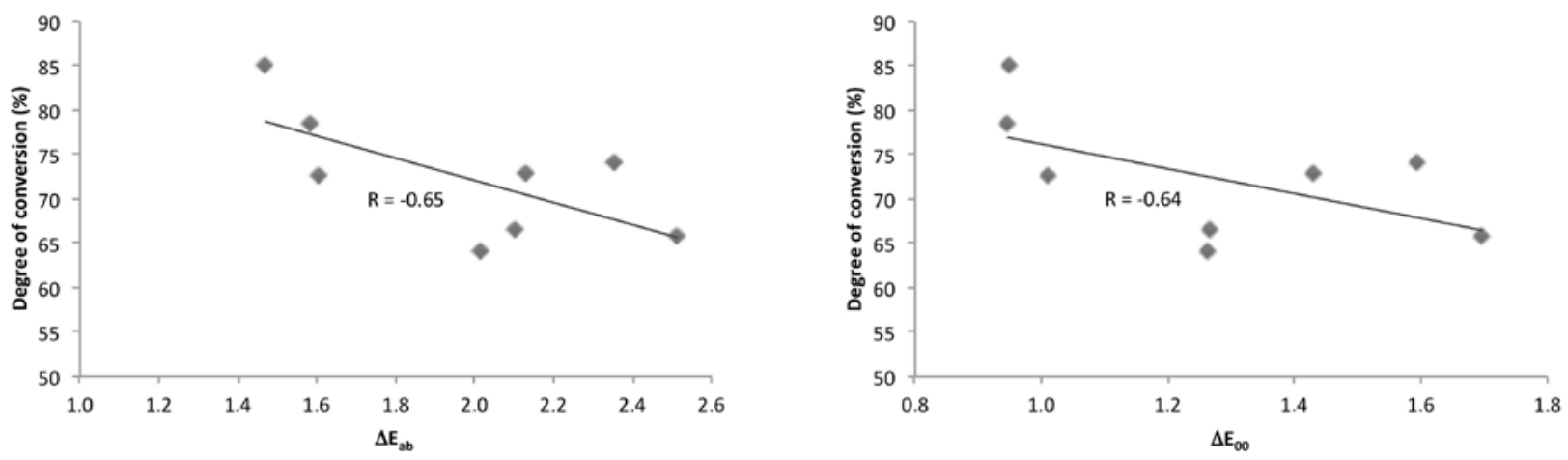

Figure 1. Correlation plots between the degree of conversion (in \%) and the mean $\Delta \mathrm{E}_{\mathrm{ab}}$ or $\Delta \mathrm{E}_{00}$ values in the evaluated period.

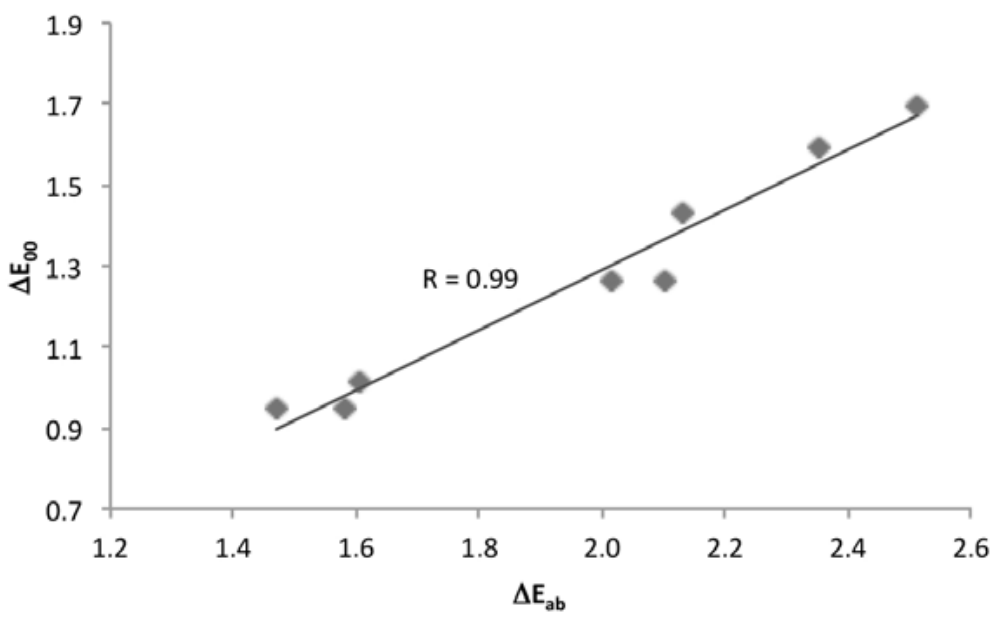

Figure 2. Correlation plot between the mean $\Delta \mathrm{E}_{\mathrm{ab}}$ and $\Delta \mathrm{E}_{00}$ values in the evaluated period. 
possible explanation would be the experimental design of the present study, which assessed the final color of ceramic veneers after cementation, evaluating the whole set (ceramic veneer, luting agent, and tooth substrate), rather than the resin cement only. By evaluating the set, color change tends to be minimized, when compared to studies in which cement specimens are directly exposed to degradation. In the present study, due to the cementation of laminates over the tooth substrate, with a thin layer of cement not directly exposed to the medium, only at the margins, the results tend to be closer to the ones found in clinical situations. This phenomenon is more relevant on the cervical margins of ceramic veneers. Hence, clinicians should give special attention to the proper positioning of the finishing lines, using the gingival or slightly subgingival level to minimize this phenomenon. Despite the favorable result obtained for dual-cured resin cement in the present study in terms of color stability, working time - limited by the chemical reaction - is an important clinical disadvantage, especially in cases of multiple veneers. Thus, lightcured resin cement is still the material of choice for the cementation of veneers because of its large working time and long-term color stability $(5,6)$. The composite resins assessed, both at room temperature and pre-heated, had statistically similar $\Delta \mathrm{E}$ values, which is in accordance with the literature (12), indicating that photoactivated materials provide good esthetic outcomes and that composite resins can also be indicated for the cementation of ceramic veneers.

During the cementation of ceramic veneers, the polymerization of light-cured luting materials may be affected if the ceramic restorations significantly attenuate the irradiance of the light-curing unit. This is a clinically relevant issue, since the properties of light-cured resin-based materials could change depending on the ceramic type and thickness $(13,22)$. Several factors can influence the translucency of ceramic restorations, such as shade, thickness, surface roughness, polishing, volume fraction of porosity and crystalline phase (23). A recent systematic review and meta-analysis evaluated how variations in thickness of lithium disilicate restorations influenced the degree of conversion of the resin cements. It was concluded that the degree of conversion of cements was significantly decreased when ceramic thickness increased. Thicknesses greater than $1.0 \mathrm{~mm}$ were shown to considerably reduce the degree of conversion of dual- or light-cured materials (24).

The cement thickness obtained in this study was the result of a luting procedure carried out by a single operator, after standardization in a pilot study. In an effort to simulate clinical conditions, the cement thickness was not standardized using spacers, as reported in previous studies (25). The mean cement thickness was $133.4 \pm 29.0 \mu \mathrm{m}$ (coefficient of variation of 22\%), considering the use of various luting materials (resin cements and composite resins), and the fact that they have different viscosities. Previous in vitro studies also reported cement thicknesses similar to ours, varying from approximately $100 \mu \mathrm{m}$ to $160 \mu \mathrm{m}(25,26)$.

The second hypothesis of the present study was also rejected, since storage time influenced the final color of veneers after cementation in the case of the microfilled composite resin. The longer the storage time, the larger the change in color, which can be explained by the fact that the specimens were stored for 1 year in distilled water, after which period the luting agent went through water sorption, degradation, and plasticization, affecting its color in the long-term. Several studies that have evaluated the color stability of cemented ceramic veneers and luting materials use different artificial accelerated aging methods, with similar results to those of the present study, showing that aging and time influence color stability $(12,27)$. Accelerated aging has been the most widely reported method for the aging of specimens and assessment of color stability in the long run, but few studies store the specimens in water for periods longer than 6 months. In this study, the specimens were stored in distilled water at $37{ }^{\circ} \mathrm{C}$ for 12 months in an attempt to better simulate clinical aging in the oral environment. Regarding the outcomes after 1 year-storage, only the groups cemented with MHCR, MCCR and MCCR-PH showed a clinically significant color change with $\triangle \mathrm{E}$ above the 50:50\% acceptability thresholds.

The assessment of color differences is of great interest for dental materials and clinical situations. This study used two different color difference parameter, $\Delta \mathrm{E}_{\mathrm{ab}}$ and $\Delta \mathrm{E}_{00}$, to evaluate the color stability of different luting materials for laminate veneers over a 1 year time period. Both parameters are important, because $\Delta \mathrm{E}_{\mathrm{ab}}$ is well known in Dentistry and many studies over the years have used this parameter to determine color difference. However, in the last five years, the use of CIEDE2000 formula and the respective $\Delta \mathrm{E}_{00}$ 
has been encouraged as a more adequate tool for evaluation of the color of resin composites. Also, it has been shown that the CIEDE2000 formula has better match to observer responses when compared to CIELab color difference. Besides resulting in different $\Delta \mathrm{E}$ values and with different acceptability thresholds, the literature reports significant correlations between $\Delta \mathrm{E}_{\mathrm{ab}}$ and $\Delta \mathrm{E}_{00}$ for different shades of composite resins, with $\mathrm{r}^{2}$ of 0.99 (17). The present study, also evaluating resin-based materials, corroborates this result, with a strong significant positive correlation coefficient of 0.99.

The DC can be a way to assess the mechanical properties of polymeric materials (28). The higher the $\mathrm{DC}$, the better the properties and, consequently, the better the color stability in the long-term. In this study, no statistically significant difference was observed between the groups, and the hypothesis that there would not be any difference in the DC of the luting agents was accepted. Previous studies also showed that some properties, such as monomer conversion and flexural strength, were not significantly affected by composite pre-heating (29). One of the possible explanations for this fact is that, when a composite is heated to $60^{\circ} \mathrm{C}$ and removed from the heating device, its temperature can decrease approximately $40 \%$ in the first minute (30). Thus, considering such a decrease, it is possible that the resin temperature might not be enough to significantly increase the composite mechanical properties (29). The dual-cured resin cement had the highest DC (85.1\%), since its two activation modes allowed higher monomer conversion. Dual-cured cements subjected to photo-activation usually had a better DC and better physicochemical properties when compared to light-cured materials (7). Even though no significant difference was found in the $\mathrm{DC}$, there was a moderate to strong negative correlation between $\Delta \mathrm{E}_{\mathrm{ab}}$ and $\mathrm{DC}$, and $\Delta \mathrm{E}_{00}$ and $\mathrm{DC}$. This correlation was already expected, confirming an important relationship between DC and color stability.

Pre-heating of composite resins has been used as a clinical alternative to decrease the viscosity and to improve the use of composite resins both in restorative procedures and in the cementation of ceramic veneers. There are several methods described in the literature to pre-heat resin-based materials, such as the Calset and Therma-Flo composite warmers, ovens, light of the dental unit chair, hand holding, thermocycling machines, and wax warmers $(31,32)$. The present study used an oven to pre-heat the composite resins, as has been previously described in the literature $(12,33)$. This method is simple, the temperature can be easily controlled, and it is commonly available in the dental clinics. Also, it is important to mention that the cost and availability of some of the specific devices for pre-heating of composites can be a limiting factor for their use (31). The use of ovens did not have a negative effect on the properties of the assessed materials, providing a less costly alternative for clinical cementation of laminate veneers.

The literature reports, in some cases, an increase in DC with pre-heating of resins (33), as high temperatures increase the mobility of monomers, the collision between molecules, and the amount of bonds (34). The increase in DC would cause the polymer matrix to absorb less solvent and to lose fewer components to the external environment, slowing down its degradation (34). In another previous study on color stability and DC of preheated resins, pre-heating did not change color stability, but it statistically increased the DC (35). In the present study, on the other hand, pre-heating of resins did not increase the DC and also did not influence the color stability of cemented veneers.

From the clinical perspective, the results obtained in this study are favorable to the use of pre-heated composite resins for the cementation of ceramic veneers. Z100 and Durafill resins had adequate viscosity for the cementation of laminate veneers and responded well to heating, rendering their consistency even better for the cementation of veneers. It should be emphasized that not all composite resins may be indicated for pre-heating and cementation of veneers without significant interference in their physical and mechanical properties. Their composition, filler content, and photoinitiator system should be considered. Also, the thickness of the ceramic material and its fit should be considered, as more flowable materials are better indicated for thinner cement lines. Cementation with pre-heated composite resins requires higher pressure during the placement of the specimen, and in case of very thin laminates, the possibility of crack and fracture could increase.

Therefore, it is increasingly important that clinicians understand the different properties of materials for the cementation of thin ceramic veneers that are commercially available. The color stability of these materials has a crucial role, which may cause the cement film to be clinically visible 
over time. The demand for esthetic treatments with ceramic veneers requires that clinicians be careful with the choice of the luting material, as this is one of the major factors that will determine long-term treatment success.

It can be concluded that the different materials used for cementation of thin ceramic veneers influenced the final color of the restorations and the light-cured and dual-cured resin cements had similar color stability. The microfilled composite resin at room temperature and pre-heated revealed clinically relevant color change after 1 year of storage. Heating did not affect the color stability of the composite resins used, as compared to materials used at room temperature. The DC of luting agents used did not show any significant difference, and pre-heating of the composite resins did not cause their DC.

\section{Resumo}

O objetivo foi avaliar a estabilidade de cor de laminados cerâmicos de fina espessura, após a cimentação com cimentos resinosos e resinas compostas em temperatura ambiente e aquecida $\left(60{ }^{\circ} \mathrm{C}\right)$, durante 12 meses; bem como determinar o grau de conversão dos diferentes materiais para cimentação. Foram utilizados dois cimentos resinosos [AllCem Veneer, cimento resinoso fotoativado (LRC) e AllCem, cimento resinoso dual (DRC)] e três resinas compostas [Z100 (MNCR - resina composta de partículas finas),

Herculite Classic (MHCR - resina composta micro-hibrida) e Durafill (MCCR - resina composta microparticulada)] para cimentação de laminados cerâmicos a base de silicato de lítio (Suprinity, cor B2-HT, Vita Zahnfabrik) com 0,8 mm de espessura, sobre esmalte bovino. Oitenta espécimes foram distribuidos aleatoriamente em 8 grupos de acordo com o material para cimentante $(n=10)$. Os espécimes foram armazenados a $37^{\circ} \mathrm{C}$ em água destilada. Os parâmetros do CIELab foram determinados $24 \mathrm{~h}$ após a cimentação (baseline), 7, 30 , 90, 180 dias e 12 meses. Outros três espécimes foram preparados para avaliação de grau de conversão, realizada por espectroscopia micro-Raman. Os dados foram analisados por ANOVA e teste de Tukey $(\alpha=5 \%)$. Para $\Delta \mathrm{E}_{\mathrm{ab}}$ e $\Delta \mathrm{E}_{00}$, houve diferenças estatisticamente significantes para o material de cimentação $(p<0,001)$, tempo $(p<0,001)$ e interação dupla $(p<0,001)$. Os grupos cimentados com o MHCR ( 1 ano), MCCR (90 dias e 1 ano) e MCCR-PH ( 1 ano) foram os únicos com valores de $\Delta \mathrm{E}$ maiores que o limite de aceitabilidade. Todos os demais grupos mantiveram seu $\Delta E$ menor que o limite de aceitabilidade ao final de 1 ano de armazenamento em água destilada. Em relação ao grau de conversão, não foram observadas diferenças estatisticamente significantes entre os materiais para cimentação avaliados $(p=0,127)$. 0 grau de conversão variou entre 64,0\% (MNCR-PH) e 85,1\% (DRC). Correlações negativas moderadas a fortes não significativas foram observadas entre a média $\Delta \mathrm{E}_{\mathrm{ab}}$ e grau de conversão $(R=-0,65)$ e $\Delta E_{00}$ e grau de conversão $(R=-$ $0,64)$. Observou-se uma correlação positiva forte significativa nos valores médios de $\Delta \mathrm{E}_{\mathrm{ab}}$ e $\Delta \mathrm{E}_{00}(\mathrm{R}=0,99)$. Pode-se concluir que os diferentes agentes cimentantes utilizados na cimentação de laminados cerâmicos de espessura fina influenciaram na cor final das restaurações. $O$ aquecimento das resinas compostas não implicou em alteração do grau de conversão.

\section{References}

1. Vichi A, Ferrari M, Davidson CL. Color and opacity variations in three different resin-based composite products after water aging. Dent Mater 2004;20:530-534.

2. Chaiyabutr Y, Kois JC, Lebeau D, Nunokawa G. Effect of abutment tooth color, cement color, and ceramic thickness on the resulting optical color of a CAD/CAM glass-ceramic lithium disilicate-reinforced crown. J Prosthet Dent 2011;105:83-90.

3. Rodrigues RB, Lima E, Roscoe MG, Soares CJ, Cesar PF, Novais VR. Influence of Resin Cements on Color Stability of Different Ceramic Systems. Braz Dent J 2017;28:191-195.

4. Rosenstiel SF, Land MF, Crispin BJ. Dental luting agents: A review of the current literature. J Prosthet Dent 1998;80:280301.

5. Hekimoglu C, Anil N, Etikan I. Effect of accelerated aging on the color stability of cemented laminate veneers. Int $J$ Prosthodont 2000;13:29-33.

6. Nathanson D, Banasr F. Color stability of resin cements--an in vitro study. Pract Proced Aesthet Dent 2002;14:449-455;quiz 456.

7. Hofmann N, Papsthart G, Hugo B, Klaiber B. Comparison of photo-activation versus chemical or dual-curing of resinbased luting cements regarding flexural strength, modulus and surface hardness. J Oral Rehabil 2001;28:1022-1028.

8. Koishi $Y$, Tanoue N, Atsuta M, Matsumura H. Influence of visible-light exposure on colour stability of current dualcurable luting composites. J Oral Rehabil 2002;29:387-393.

9. Buchalla W, Attin T, Hilgers RD, Hellwig E. The effect of water storage and light exposure on the color and translucency of a hybrid and a microfilled composite. J Prosthet Dent 2002;87:264-270.

10. Wagner WC, Aksu MN, Neme AM, Linger JB, Pink FE, Walker $\mathrm{S}$. Effect of pre-heating resin composite on restoration microleakage. Oper Dent 2008;33:72-78.

11 Lovell LG, Lu H, Elliott JE, Stansbury JW, Bowman CN. The effect of cure rate on the mechanical properties of dental resins. Dent Mater 2001;17:504-511.

12. Almeida JR, Schmitt GU, Kaizer MR, Boscato N, Moraes RR. Resin-based luting agents and color stability of bonded ceramic veneers. J Prosthet Dent 2015;114:272-277.

13. Runnacles P, Correr GM, Baratto Filho F, Gonzaga CC, Furuse AY. Degree of conversion of a resin cement light-cured through ceramic veneers of different thicknesses and types. Braz Dent J 2014;25:38-42.

14. Heffernan MJ, Aquilino SA, Diaz-Arnold AM, Haselton DR, Stanford CM, Vargas MA. Relative translucency of six allceramic systems. Part II: core and veneer materials. J Prosthet Dent 2002;88:10-15.

15. E'clairage Cld. CIE Technical Report: Colorimetry. CIE Pub No. 15.3. Vienna, Austria: CIE Central Bureau; 2004.

16. Luo MR, Cui G, Rigg B. The development of the CIE 2000 colour-difference formula: CIEDE2000. Color Research and Application 2001;26:340-350.

17. Lee YK, Powers JM. Comparison of CIE lab, CIEDE 2000, and DIN 99 color differences between various shades of resin composites. Int J Prosthodont 2005;18:150-155.

18. Paravina RD, Ghinea $R$, Herrera $\amalg$, Bona $A D$, Igiel $C$, Linninger $\mathrm{M}$ et al. Color difference thresholds in dentistry. J Esthet Restor Dent 2015;27:S1-9.

19. Pires LA, Novais PM, Araujo VD, Pegoraro LF. Effects of the type and thickness of ceramic, substrate, and cement on the 
optical color of a lithium disilicate ceramic. J Prosthet Dent 2017;117:144-149.

20. Yap AU, Chandra SP, Chung SM, Lim CT. Changes in flexural properties of composite restoratives after aging in water. Oper Dent 2002;27:468-474.

21. Albuquerque PP, Moreira AD, Moraes RR, Cavalcante LM, Schneider LF. Color stability, conversion, water sorption and solubility of dental composites formulated with different photoinitiator systems. J Dent 2013;41:e67-72.

22. Zeighami S, Hemmati YB, Falahchai SM. Effect of ceramic thickness and cement color on final shade of all ceramic restorations: a systematic review. Sch Acad J Biosci 2017;5:425-432.

23. Sravanthi Y, Ramani YV, Rathod AM, Ram SM, Turakhia H. The comparative evaluation of the translucency of crowns fabricated with three different all-ceramic materials: an in vitro study. J Clin Diagn Res 2015;9:ZC30-34.

24. Martins FV, Vasques WF, Fonseca EM. How the Variations of the Thickness in Ceramic Restorations of Lithium Disilicate and the Use of Different Photopolymerizers Influence the Degree of Conversion of the Resin Cements: A Systematic Review and Meta-Analysis. J Prosthodont 2019;28:e395-e403.

25. Montero J, Gomez-Polo C. Effect of ceramic thickness and cement shade on the final shade after bonding using the 3D master system: a laboratory study. Clin Exp Dent Res 2016;2:57-64.

26. Hernandes DK, Arrais CA, Lima E, Cesar PF, Rodrigues JA. Influence of resin cement shade on the color and translucency of ceramic veneers. J Appl Oral Sci 2016;24:391-396.

27. Archegas LR, Freire A, Vieira S, Caldas DB, Souza EM. Colour stability and opacity of resin cements and flowable composites for ceramic veneer luting after accelerated ageing. J Dent 2011;39:804-810.

28. Novais VR, Raposo LH, Miranda RR, Lopes CC, Simamoto PCJ,
Soares CJ. Degree of conversion and bond strength of resincements to feldspathic ceramic using different curing modes. J Appl Oral Sci 2017;25:61-68.

29. Froes-Salgado NR, Silva LM, Kawano $Y$, Francci C, Reis A, Loguercio AD. Composite pre-heating: effects on marginal adaptation, degree of conversion and mechanical properties. Dent Mater 2010;26:908-914.

30. Daronch M, Rueggeberg FA, Moss L, de Goes MF. Clinically relevant issues related to preheating composites. J Esthet Restor Dent 2006;18:340-350; discussion 351.

31. Arora V, Arora P, A. SA, Fahmi MK. Devices \& methods for pre-heating/pre-warming dental resin composites: a critical appraisal. Int J Oral Health Med Res 2017;4:52-55.

32. Jin MU. Prepare the pre-heated composite resin. Restor Dent Endod 2013;38:103-104.

33. Theobaldo JD, Aguiar FHB, Pini NIP, Lima D, Liporoni PCS, Catelan A. Effect of preheating and light-curing unit on physicochemical properties of a bulk fill composite. Clin Cosmet Investig Dent 2017;9:39-43.

34. Silva JC, Rogerio Vieira R, Rege IC, Cruz CA, Vaz LG, Estrela $\mathrm{C}$ et al. Pre-heating mitigates composite degradation. J Appl Oral Sci 2015;23:571-579.

35. Mundim FM, Garcia Lda F, Cruvinel DR, Lima FA, Bachmann L, Pires-de-Souza Fde C. Color stability, opacity and degree of conversion of pre-heated composites. J Dent 2011;39:e25-29.

Received July 5, 2019 Accepted August 15, 2019 